\title{
BMJ Open Trends in market share of leading cigarette brands in the USA: national survey on drug use and health 2002- 2013
}

\author{
Anushree Sharma, ${ }^{1}$ Brian V Fix, ${ }^{1}$ Cristine Delnevo, ${ }^{2} \mathrm{~K}$ Michael Cummings, ${ }^{3}$ \\ Richard J O'Connor ${ }^{1}$
}

To cite: Sharma A, Fix BV, Delnevo $C$, et al. Trends in market share of leading cigarette brands in the USA: national survey on drug use and health 2002-2013. BMJ Open 2016;6:e008813. doi:10.1136/bmjopen-2015008813

- Prepublication history for this paper is available online To view these files please visit the journal online (http://dx.doi.org/10.1136/ bmjopen-2015-008813).

Received 18 May 2015 Revised 30 September 2015 Accepted 20 October 2015

CrossMark

\begin{abstract}
${ }^{1}$ Department of Health Behavior, Roswell Park Cancer Institute Buffalo, Buffalo, New York, USA ${ }^{2}$ Department of Health Education and Behavioral Science, Rutgers University School of Public Health, New Brunswick, New Jersey, USA ${ }^{3}$ Department of Psychiatry and Behavioral Sciences, Medical University of South Carolina, Charleston, South Carolina, USA
\end{abstract}

Correspondence to Dr Richard J O'Connor; Richard.OConnor@ roswellpark.org

\section{ABSTRACT}

Objectives: The main objective of this study is to examine trends in market share for leading cigarette brands, both before (2002-2008) and after (20092013) Food and Drug Administration (FDA) regulation of tobacco products.

Design Data come from the annual National Survey on Drug Use and Health from 2002 through 2013. Descriptive statistics, cross tabulations, and logistic regression were employed. Data were weighted to the US population and adjusted for cigarette consumption. Our analysis is restricted to 164343 current cigarette smokers who were at least 12 years of age or older, had smoked at least one cigarette in the 30 days prior to the survey, and reported a usual cigarette brand at the time of the survey.

Results: Over 12 years, 14 brands comprised over $77 \%$ of the cigarette market. Marlboro consistently held over $38 \%$ of the market. Newport held the second highest market share, and increased from $7.2 \%$ in 2002 to $10.9 \%$ by 2013 . Market share of Pall Mall grew by over $400 \%$ (1.7\% in 2002 vs $8.9 \%$ in 2013$)$, likely aided by the 2009 Federal excise tax increase. No clear associations of changes in market share with the implementation of FDA's regulatory authority over tobacco in 2009 were noted.

Conclusions: Tracking market share trends offers clues about brand marketing changing preferences of consumers. Rapidly growing cigarette brands should be monitored to determine if specific marketing practices or design changes are drivers, as these could represent public health concerns. Monitoring trends in cigarette market share could inform regulatory decision-making efforts related to marketing and advertising.

\section{INTRODUCTION}

Cigarettes remain one of the most heavily advertised consumer products. Since tobacco manufacturers have a keen interest in driving consumers to select their products over their competitors, they invest heavily to promote

\section{Strengths and limitations of this study}

- One of the strengths of this analysis is the large sample size afforded by National Survey on Drug Use and Health (NSDUH).

- Construction and use of cigarette consumptionbased weights offers a reflection of market share accounting for different consumption patterns.

- One of the limitations of the NSDUH data is that detail on specific subvarieties (eg, strength, length, flavour) is limited.

- As with all cross-sectional data, our inability to make inferences about brand switching is limited.

- A final limitation, to be addressed in a follow-up analysis, is that this manuscript did not address demographic correlates of market share trends.

specific brands using marketing via direct mail, cigarette packaging, point of sale and advertising via media channels. ${ }^{12}$ Since the Master Settlement Agreement (MSA) closed off many traditional advertising venues, the majority of this spending (approximately $\$ 7$ billion) is on price discounts. ${ }^{3-5}$ The amount spent on cigarette advertising and promotion by the largest cigarette companies in the USA rose from $\$ 8.05$ billion in 2010 to $\$ 8.37$ billion in 2011, due mainly to an increase in spending on price discounts, or discounts paid to cigarette retailers or wholesalers in order to reduce the price of cigarettes to consumers. ${ }^{36}$

The cigarette industry's own internal business records acknowledge the importance of advertising, observing that "...every consumer is presold, specifying his brand by name...the rise and fall of every brand of consequence has been traced in detail and their year to year success or failure shown to be the direct result of consumer advertising". 7 Thus, it is important to monitor the cigarette marketplace as 
changes in the relative popularity of brands (positive or negative) may signal changes in consumer preferences which could be influenced by marketing and/or product regulations. ${ }^{89}$ Recent studies have addressed the trends of other tobacco products in the market to identify important shifts, ${ }^{10}{ }^{11}$-for example, while cigarette sales have declined in the overall market, the sales of flavoured cigars have continued to increase. ${ }^{10}$ Other studies have demonstrated that menthol cigarettes have held relatively constant market share compared to non-menthol cigarettes ${ }^{12}{ }^{13}$; an important finding given young smokers are more likely to smoke mentholated cigarettes compared to non-mentholated cigarettes. ${ }^{13}$ Overall, monitoring trends in tobacco brands is important in as much as it could signal changes in consumer behaviours that may warrant further investigation. ${ }^{14}{ }^{15}$ In addition, monitoring trends in market share could be used to inform regulatory decision-making efforts. Understanding how market share of cigarettes changes in response to regulation could serve as a useful model for understanding and/or predicting how newly introduced products might perform once they are introduced into the marketplace.

The primary aim of this analysis was to assess trends in cigarette brand market share via a secondary data analysis of a large, nationally representative data set (the National Survey on Drug Use and Health). This paper presents cigarette brand trends in America as they were reported from 2002 through 2013, which encompasses the period before (2002-2008) and after (2009-2013) Congress authorised Food and Drug Administration (FDA) regulation of tobacco products. ${ }^{16}$ These newly introduced regulations, including a ban on descriptive terms such as 'light' and 'mild', as well as a 2009 federal excise tax increase on cigarettes, have the potential to cause changes in the market share of cigarette brands. In addition, tobacco manufacturers of brands with a larger market share prior to the introduction of these regulations might be better positioned to withstand the regulatory burden than smaller manufacturers, helping to maintain their portion of the market.

\section{METHODS}

\section{Data source}

Data for the current study come from the 2002 through 2013 public use data sets of the National Survey on Drug Use and Health (NSDUH), a nationally representative cross-sectional survey that assesses substance use behaviours in the USA civilian, non-institutionalised population aged $12+.{ }^{17}$ Each year, approximately 70000 eligible individuals complete the survey. The data before 2002 was collected using a different sampling frame, thus previous time periods were not included in our analysis. Thus, at the time the study was conducted researchers had access to NSDUH data from 2002 to 2013. Data were analysed in 2014.

NSDUH uses a 50 state design with independent, multistage area probability samples for each State and the District of Columbia to provide nationally representative data regarding tobacco use, alcohol use and other illicit drug use. Data are collected using computerassisted personal interviewing for basic questions and audio computer-assisted self-interviewing to complete questions on substance use to encourage more truthful reporting. ${ }^{17}$ Complete information regarding data collection methods can be found online at http://www.oas. samhsa.gov/nsduh/methods.cfm.

\section{Cigarette brand measures}

Our analysis is restricted to 164343 current cigarette smokers who were at least 12 years of age or older, and had smoked at least one cigarette in the 30 days prior to the survey. Participants were asked to report if they had smoked a cigarette (even a part of a cigarette) in the past 30 days. If they acknowledged they had smoked in the past 30 days, they were then asked to report on the brand of cigarette they smoked most often. Using this usual brand variable, we conducted an initial examination of frequencies and focused our analyses to those brands that were among the top 10 brands for any of the years during the study period (2002-2013), resulting in a 'short list' of 14 brands. Note that our analysis focuses only on brand families, not sub-brands (eg, Full-Flavor vs 'gold'), as the survey does not gather precise brand variant data.

\section{Weight adjustment}

The default weight in the public use data set (ANALWT3) weights the sample to the US population. Since we wanted to do an analysis looking at the market share for the cigarette brands, we adjusted these sampling weights to better reflect consumption patterns among the sample. ANALWT3 was multiplied by the number of cigarettes consumed on average each day, and by the number of days in the past month that participants reported smoking. Thus, the adjusted weight reflects the number of cigarettes smoked over the past 30 days among current smokers. The weight adjustment allows us to take into account consumption patterns among smokers and gives us a better indicator of the overall market with regards to the number of actual cigarettes smoked.

\section{Statistical analysis}

We used SUDAAN V.11 (RTI International, Research Triangle Park, North Carolina, USA) running in SAS V.9.4 (SAS Institute, Cary, North Carolina, USA) to account for the complex sampling frame. Once the data was collected, we determined the market share of all the top 10 cigarette brands using a crosstabs procedure which took into account the new weight variable we had constructed to account for the actual number of cigarettes smoked with regards to overall market share. We also conducted a trend analysis to look at changes among individual cigarette brands over the 12-year period using logistic regression. We observed a quadratic 
Table 1 Market Share of brands appearing in the top 10 in any year: NSDUH 2002-2013

\begin{tabular}{|c|c|c|c|c|c|c|c|c|c|c|c|c|c|}
\hline & 2002 & 2003 & 2004 & 2005 & 2006 & 2007 & 2008 & 2009 & 2010 & 2011 & 2012 & 2013 & $\begin{array}{l}\text { Per cent } \\
\text { change } \\
2002-2013\end{array}$ \\
\hline $\begin{array}{l}\text { American Spirit } \\
\text { RJR }\end{array}$ & 0.26 & 0.47 & 0.30 & 0.48 & 0.63 & 0.63 & 0.75 & 0.98 & 1.35 & 1.04 & 1.47 & 1.70 & +553.8 \\
\hline $\begin{array}{l}\text { Basic } \\
\text { PMUSA }\end{array}$ & 6.10 & 4.67 & 5.29 & 5.62 & 5.88 & 5.76 & 4.18 & 4.37 & 3.17 & 2.45 & 1.54 & 2.01 & -67.1 \\
\hline $\begin{array}{l}\text { Camel } \\
\text { RJR }\end{array}$ & 6.24 & 6.35 & 7.21 & 6.36 & 7.50 & 7.92 & 8.11 & 8.32 & 7.97 & 7.79 & 7.34 & 7.77 & +24.5 \\
\hline $\begin{array}{l}\text { Doral } \\
\text { RJR }\end{array}$ & 6.77 & 6.59 & 5.17 & 3.98 & 4.19 & 4.45 & 3.61 & 4.53 & 1.62 & 1.90 & 0.70 & 0.73 & -89.2 \\
\hline $\begin{array}{l}\text { GPC } \\
\text { RJR }\end{array}$ & 2.64 & 2.20 & 2.52 & 1.83 & 1.56 & 1.74 & 1.06 & 1.22 & 0.94 & 0.79 & 0.64 & 0.34 & -87.1 \\
\hline $\begin{array}{l}\text { KOOL } \\
\text { RJR }\end{array}$ & 3.10 & 3.26 & 2.86 & 2.55 & 3.06 & 3.25 & 2.93 & 2.53 & 2.96 & 2.51 & 2.31 & 1.58 & -49.0 \\
\hline $\begin{array}{l}\text { Marlboro } \\
\text { PMUSA }\end{array}$ & 38.44 & 38.24 & 39.22 & 39.60 & 39.19 & 39.28 & 41.02 & 39.34 & 41.21 & 39.17 & 38.34 & 38.10 & -0.9 \\
\hline $\begin{array}{l}\text { Newport } \\
\text { Lorillard* }^{*}\end{array}$ & 7.23 & 7.54 & 7.66 & 7.26 & 8.97 & 8.42 & 9.06 & 8.78 & 9.77 & 10.14 & 10.93 & 10.89 & +50.6 \\
\hline $\begin{array}{l}\text { Pall Mall } \\
\text { RJR }\end{array}$ & 1.66 & 1.68 & 2.35 & 1.97 & 2.06 & 2.63 & 3.13 & 4.77 & 6.93 & 8.11 & 8.93 & 8.92 & +437.4 \\
\hline $\begin{array}{l}\text { Parliament } \\
\text { PMUSA }\end{array}$ & 0.96 & 1.36 & 1.30 & 1.48 & 1.38 & 1.31 & 1.50 & 0.94 & 1.22 & 1.49 & 0.64 & 0.92 & -4.2 \\
\hline $\begin{array}{l}\text { Salem } \\
\text { RJR }\end{array}$ & 2.32 & 2.29 & 2.63 & 1.43 & 1.87 & 1.96 & 1.90 & 0.94 & 1.43 & 1.16 & 1.09 & 0.96 & -58.6 \\
\hline $\begin{array}{l}\text { USA Gold } \\
\text { Commonwealth }\end{array}$ & 1.20 & 1.86 & 1.24 & 2.34 & 2.36 & 2.61 & 2.08 & 2.20 & 2.16 & 1.49 & 1.60 & 1.37 & +14.2 \\
\hline $\begin{array}{l}\text { Virginia Slims } \\
\text { PMUSA }\end{array}$ & 2.92 & 2.02 & 2.16 & 1.53 & 1.65 & 2.09 & 1.68 & 1.65 & 1.19 & 1.13 & 1.35 & 0.59 & -79.8 \\
\hline $\begin{array}{l}\text { Winston } \\
\text { RJR }\end{array}$ & 3.91 & 3.92 & 2.99 & 4.14 & 3.17 & 3.04 & 3.12 & 2.35 & 2.08 & 2.53 & 2.38 & 2.11 & -46.0 \\
\hline $\begin{array}{l}\text { All Other } \\
\text { Reported Brands }\end{array}$ & 16.27 & 17.55 & 17.10 & 19.43 & 16.52 & 14.92 & 15.87 & 17.08 & 16.00 & 18.3 & 20.76 & 22.02 & +35.3 \\
\hline
\end{tabular}

trend with Pall Mall, thus we assessed the quadratic trend for Pall Mall using a yearxyear term in the logistic regression model.

\section{RESULTS}

The results of the overall cigarette market share analysis are presented in table 1 . Marlboro consistently held over $38 \%$ of the market in any given year and has been relatively stable in terms of its overall share of the market. Newport held the second highest market share overall, and increased over time from $7.23 \%$ in 2002 to $10.89 \%$ by 2013. More dramatic are the gains of Pall Mall, which in 2002 commanded only $1.66 \%$ of the overall market share, but by 2013 had grown to $8.92 \%$, an increase of $437 \%$. Pall Mall appears to have grown most after 2007increasing $239 \%$ in only 6 years. Another brand with large growth is American Spirit. It increased from a negligible $0.26 \%$ in 2002 to over $1.70 \%$ in 2013, representing a relative growth of $554 \%$ over this time span. Camel, Pall
Mall and American Spirit were all owned by Reynolds American in 2013, and their combined market share was approximately $18 \%$. Market share of other brands such as Doral and Basic declined between 2002 and 2013.

\section{Trend tests}

Most of the brands in the analysis had some fluctuations regarding their market share from any given year to the next. However, in terms of the overall patterns the linear trend tests which were conducted for Newport, Pall Mall and American Spirit using logistic regression all indicated that year was significantly associated with odds of brand selection. The $p$ value for the Wald $F$ test was $\mathrm{p}<0.0001$. For Camel, the $\mathrm{p}$ value for the Wald $\mathrm{F}$ test was $\mathrm{p}=0.001$ (year was treated as a continuous variable in the model). The trend test for Marlboro was not significant with a $\mathrm{p}$ value for the Wald $\mathrm{F}$ test $=0.65$. We also noticed (by visual inspection) that Pall Mall and Basic had nonlinear growth. Quadratic trend tests for Pall Mall and Basic showed significance at the $\mathrm{p}<0.0001$ level. 


\section{Subtypes}

A crude examination of how subtypes (Full Flavor vs all other variants) might influence overall trends was conducted. Between 2002 and 2004, participants were asked 'During the past 30 days, what type of cigarettes did you smoke most often?' The response options were Lights, Ultralights or Full Flavor. Between 2005 and 2013, participants were asked the same question but there was a new response added for 'Mediums'. Owing to the difference in the manner the question was asked, we elected to analyse the subtypes as Full Flavor compared to all other subtypes. The market share of Pall Mall in 2002 was comprised of 72.2\% Full Flavor, compared to $42.1 \%$ in 2013, a substantial decline. In contrast, for Camel, the proportion of their market share made up of Full Flavor subtypes increased from $37.1 \%$ to $48.9 \%$. For Marlboro, Newport, American Spirit the proportion of their market share accounted for by Full Flavor variants was relatively stable between 2002 and 2013. A similar analysis examined how menthol cigarettes might influence market share trends for the 20042013 period (a different question wording was used in 2002-2003). The menthol proportion for Pall Mall increased from $11.7 \%$ in 2004 to $21.1 \%$ in 2013. The menthol fraction of Camel increased substantially over the same period (5.8-32.7\%). The share of Newport use attributed to menthol decreased from $99.3 \%$ to $91.2 \%$ (which corresponds to the introduction of a non-menthol version of Newport in 2010). Menthol represents a relatively small, but growing, proportion of the Marlboro market ( $10 \%$ in 2004 vs $14.5 \%$ in 2013 ).

\section{DISCUSSION}

We used a very large, nationally representative data set to monitor market share for the most popular cigarette brands in America during a key time period. The data here indicate growth and decline in certain brands over past 12 years. While there are no clear associations with the implementation of FDA's regulatory authority over tobacco in 2009, this time period saw a major recession in 2007 and an increased federal excise tax in 2009. ${ }^{18}$ Driven in part by these economic conditions, the data indicated rapid growth in market share of brands like Pall Mall. Pall Mall was acquired by RJR and repositioned for marketing purposes as a premium quality brand at a discount price. ${ }^{19}$ The timing of the marketing was critical to the growth of Pall Mall because it was positioned as an attractive brand for smokers who might have been looking to maximise on their cigarette quality for a low price. ${ }^{19-21}$ At the same time, longitudinal data showed that some smokers of premium brands were paying less for their cigarettes than those buying identified discount products, ${ }^{19}$ suggesting the existence of substantial price discounting, even for their premium brands, which may have preserved their market share despite the poor economy.

Changes in marketing practices play a key role in the market share changes that are observed in our data. For example, company reports by RJ Reynolds in 2007 indicate that they intended to focus their efforts on a few key brands, including "...two premium brands, CAMEL and KOOL, and a value brand, PALL MALL". ${ }^{22}$ RJR reformulated and reintroduced the brand as a premium discount (old time premium name with a low price). The new packaging and line extensions for Pall Mall reflected a brighter, more colourful design and was advertised to consumers using ads placed in prominent magazines such as Entertainment Weekly, Glamour and Vanity Fair. ${ }^{23}$ This helped to make the brand more prominent, marketed to consumers as a brand that 'differentiates itself from other value offerings by delivering a high-quality, longer-lasting cigarette at an affordable price' and due to these reasons the brand 'retain(s) a high percentage of adult smokers who try the brand'. ${ }^{24}$ These changes appear to have been effective in promoting uptake of the brand among current smokers, as market share has increased substantially since 2007. Timing was critical to Pall Mall's success given the federal tax hike on cigarettes in $2009^{19-21}$ positioning as a premium discount may have attracted smokers.

Findings are mixed with respect to traditional premium brands. Marlboro has maintained its market dominance, controlling the largest proportion of the market share (between $38.2 \%$ and $41.2 \%$ ). However, despite the proliferation of new sub varieties of Marlboro over the past decade (eg, Skyline, Black, Blend $54)$, it does not seem to have gained additional brand share. PM USA appears to be consolidating its marketing efforts behind Marlboro, as its other major brands (Basic, Parliament and Virginia Slims) declined in market share. Basic was a branded discount and historically attracted price-seeking smokers who might have otherwise smoked Marlboro; the sharp decline in this brand may be attributable in part to promoting new variants and price discounting of Marlboro.

Reynolds American owns two other major growth brands: Camel and American Spirit. Our findings reflecting the overtaking of Camel by Pall Mall and significant growth of American Spirit are corroborated by Reynolds-American investor reports. ${ }^{25}$ These reports also predict these brands to have continued growth in the years ahead. ${ }^{25}$ American Spirit (produced by RAI subsidiary Santa Fe Natural Tobacco Company) has been positioned as 'natural' and 'additive-free' and leverages Native American imagery to connote connection to nature. Indeed, many consumers view such cigarettes as less hazardous. ${ }^{26}{ }^{27}$ American Spirit has recently attracted attention from regulators on the basis of its positioning, with FDA sending warning letters calling those descriptors unauthorised modified risk claims. Newport, the leading menthol brand, continues to gain market share in a near-linear fashion. This appears to be the primary reason that Reynolds American announced in 2014 it would be acquiring Lorillard. ${ }^{28}$ This deal was approved in mid-2015, and Reynolds now owns the primary growth cigarette brands in the US market, while 
shedding declining ones (Winston, KOOL and Salem were sold to Imperial Tobacco). At the same time, the possibility exists that new ownership could revive a flagging brand like Winston through aggressive marketing, as Reynolds appears to have done with Pall Mall (which it acquired by merger with Brown and Williamson in 2004, which had acquired it from American Tobacco in 1994).

Age also plays a role in brand share. Younger smokers tend to initiate with and prefer premium cigarettes brands, so as fewer young people take up smoking (as has happened in the past decade), the brands popular with older smokers may become more dominant. ${ }^{29} 30$ Older, mainly white smokers with lower incomes, switched to discounts and are aging out of the market (ie, they will quit or die). ${ }^{14}{ }^{19}$ Purely discount brands like Basic, GPC and Doral, which attracted substantial share in the 1980s and $1990 \mathrm{~s},{ }^{31}$ lack marketing support and thus a pipeline of replacement smokers to keep them viable. Premium brands like Marlboro, Camel, Newport and American Spirit attract new smokers and maintain variants to retain older smokers. ${ }^{14}$ The increase in market share among menthol variants of Pall Mall, Camel and Marlboro is noteworthy given previous research indicating that younger smokers are more likely smoke menthols. A previously published analysis of NSDUH survey data from 2004 through 2010 found that menthol cigarettes were more commonly used by younger smokers $-56.7 \%$ of $12-$ 17-year-old smokers used a menthol brand versus $30-35 \%$ of smokers over $25 .{ }^{13}$

It is an important distinction to make that while overall cigarette consumption is decreasing over the years, there are numerous other types of tobacco products like e-cigarettes, cigarillos and moist snuff which are increasing in popularity and offering an alternative to people who may be cutting down on cigarette consumption due to increased regulations and economic pricing. ${ }^{11}{ }^{32}$ The overall cigarette market share is affected by policy and regulations and the changes in market share are reflective of these forces. It is thus imperative to monitor changes that are occurring in the overall cigarette market shares. ${ }^{33}$

Shifts in market share could be the result of tobacco control policies enacted by the government or they could be due to changes in marketing practices by the cigarette manufacturers. It is important to understand factors associated with large gains, as these could represent concerns for public health. ${ }^{15} 34{ }^{35}$ For example, if substantial growth in the market share of a certain brand is observed among adolescents, marketing practices for the brand could come under scrutiny from the FDA. In addition, monitoring trends in cigarette market share could be used to inform regulatory decisionmaking efforts with respect to new products introduced into the marketplace. Understanding how market share of cigarettes changes in response to marketing and advertising regulation could serve as a useful model for predicting how the marketing of substantially equivalent products might be regulated. Finally, as different companies acquire new brands, market surveillance may reveal how new ownership impacts market share.

In terms of public health, the implication is that changes in consumer behaviour can be influenced by changes in marketing, leading to certain brands or products gaining market share. Tracking the trends in the market share of cigarette brands offers clues about the success of brand marketing and provides indications about changing preferences of consumers. ${ }^{32} 33$ Our study captured trends over a 12-year period between 2002 and 2013, and offers perspective on how changing market conditions were associated with changes in brand market share. The total cigarette consumption in the USA has been declining steadily since $1998 .{ }^{36}$ Between the period of 2005 and 2013 the largest declines were seen in the adult age group of 18-24-year olds. ${ }^{37}$ However, this decline in the use of cigarettes may be partially offset by the increasing popularity of other tobacco products like cigarillos. ${ }^{10} 37$ This is especially true among young people. A recent study indicated that a rise in use of e-cigarettes and hookahs appears to be offsetting decreases in the use of other tobacco products, resulting in no change in overall use of tobacco products among middle and high school students. $^{38}$

\section{Strengths and limitations of study}

One of the strengths of this analysis is the large sample size afforded by NSDUH. Additionally, construction and use of cigarette consumption-based weights offers a reflection of market share accounting for different consumption patterns. Indeed, our data compare favourably to Maxwell Report estimates of brand market share for $2013^{39}$-we are within 1.5 percentage point of the Maxwell estimate for growth brands, except Marlboro $(-2.7 \%)$, with a mean absolute deviation across the six brands report in the 2013 Maxwell Report of 1.0 (see table 2). This suggests that the cigarette consumption-adjusted weighting procedure may be useful moving forward as a way to track not only brand preference, but also market share/sales.

\begin{tabular}{|c|c|c|c|}
\hline & $\begin{array}{l}2013 \\
\text { NSDUH }\end{array}$ & $\begin{array}{l}2013 \\
\text { Maxwell }\end{array}$ & Difference \\
\hline American Spirit & 1.7 & 1.3 & 0.4 \\
\hline Camel & 7.8 & 7.6 & 0.2 \\
\hline Marlboro & 38.1 & 40.8 & -2.7 \\
\hline Newport & 10.9 & 12.2 & -1.3 \\
\hline Pall Mall & 8.9 & 7.8 & 1.1 \\
\hline USA Gold & 1.4 & 1.1 & 0.3 \\
\hline $\begin{array}{l}\text { Mean absolute } \\
\text { deviation }\end{array}$ & & & 1.00 \\
\hline
\end{tabular}


One of the limitations of the NSDUH data is that detail on specific subvarieties (eg, strength, length, flavour) is limited. For example, we cannot determine which of the multiple varieties of Marlboro cigarettes had the highest prevalence. The survey asks a question regarding the type of cigarette used in the past 30 days with response options of lights, ultra lights and full flavour cigarettes in the 2002-2004 surveys (CIG30TYP). The response options were modified beginning with the 2005 survey and continuing through 2013 to ask about lights, ultra lights, medium and full flavoured cigarettes (CIG30TPE). With the FDA gaining authority to regulate tobacco in 2009, the use of descriptors such as 'light' and 'ultra-light' has been phased out. ${ }^{16}$ Asking questions related to subvarieties of specific brands using these response options presents a potential source of misclassification because smokers might not use these options to describe their cigarettes. Further, asking whether a participant has smoked menthol in the past 30 days using 'yes' or 'no' response options creates a possible disconnect between their usual brand and whether that brand is menthol or non-menthol. Future surveys should consider more precise methods of assessing brand preferences.

Another limitation, as with all cross-sectional data, is our inability to make inferences about brand switching. As such, these data cannot be used to examine whether, for example, former Salem smokers are migrating to Newport. A final limitation is that this analysis did not examine demographic correlates of market share trends. Consumer characteristics can also play a role in determining market changes. ${ }^{2}{ }^{40}$ A subsequent analysis is being conducted to help identify key demographic drivers of changes in the market.

Contributors RJO, AS and BVF were responsible for conception and design. AS and BVF were responsible for data analysis. AS, BVF, CD, KMC and RJO were responsible for drafting the manuscript and revising it critically for important intellectual content. All authors read and approved the final manuscript.

Funding This research received no specific grant from any funding agency in the public, commercial or not-for-profit sectors.

Competing interests KMC has served in the past and continues to serve as a paid expert witness for plaintiffs in litigation against the tobacco industry. RJO has served as a consultant to the Food and Drug Administration on tobacco regulation as a member of the Tobacco Products Scientific Advisory Committee.

Provenance and peer review Not commissioned; externally peer reviewed.

Data sharing statement No additional data are available.

Open Access This is an Open Access article distributed in accordance with the Creative Commons Attribution Non Commercial (CC BY-NC 4.0) license, which permits others to distribute, remix, adapt, build upon this work noncommercially, and license their derivative works on different terms, provided the original work is properly cited and the use is non-commercial. See: http:// creativecommons.org/licenses/by-nc/4.0/

\section{REFERENCES}

1. Hoek J, Gendall P, Gifford H, et al. Tobacco branding, plain packaging, pictorial warnings, and symbolic consumption. Qual Health Res 2012;22:630-9.
2. Hafez N, Ling PM. How Philip Morris built Marlboro into a global brand for young adults: implications for international tobacco control. Tob Control 2005;14:262-71.

3. Federal Trade Commission. Federal Trade Commission cigarette report for 2011. Washington, DC, 2013.

4. Feighery EC, Schleicher NC, Boley Cruz T, et al. An examination of trends in amount and type of cigarette advertising and sales promotions in California stores, 2002-2005. Tob Control 2008;17:93-8.

5. Chen T, Sun B, Singh V. An empirical investigation of the dynamic effect of Marlboro's permanent pricing shift. Marketing Science 2009;28:740-58.

6. Chaloupka FJ, Yurekli A, Fong GT. Tobacco taxes as a tobacco control strategy. Tob Control 2012;21:172-80.

7. Burgard JW. A study of cigarette advertising. Lorillard Tobacco Company, 1953. Bates No. 04238374-04238433: http://legacy. library.ucsf.edu/tid/kmn99d00 (accessed 28 Aug 2014).

8. Tauras JA, Peck RM, Chaloupka FJ. The role of retail prices and promotions in determining cigarette brand market shares. Rev Industrial Organ 2006;28:253-84.

9. Hyland A, Bauer JE, Li Q, et al. Higher cigarette prices influence cigarette purchase patterns. Tob Control 2005;14:86-92.

10. Delnevo CD, Giovenco DP, Ambrose BK, et al. Preference for flavoured cigar brands among youth, young adults and adults in the USA. Tob Control 2015;24:389-94.

11. Delnevo CD, Wackowski OA, Giovenco DP, et al. Examining market trends in the United States smokeless tobacco use: 2005-2011. Tob Control 2014;23:107-12.

12. Delnevo CD, Villanti AC, Giovino GA. Trends in menthol and non-menthol cigarette consumption in the USA: 2000-2011. Tob Control 2014;23:e154-5.

13. Giovino GA, Villanti AC, Mowery PD, et al. Differential trends in cigarette smoking in the USA: is menthol slowing progress? Tob Control2015;24:28-37.

14. Cummings $\mathrm{KM}$, Hyland $\mathrm{A}$, Lewit $\mathrm{E}$, et al. Discrepancies in cigarette brand sales and adult market share: are new teen smokers filling the gap? Tob Control 1997;6(Suppl 2):S38.

15. Wayne GF, Connolly GN. How cigarette design can affect youth initiation into smoking: Camel cigarettes 1983-93. Tob Control 2002;11(Suppl 1):i32-9.

16. Prevention, Family Smoking. Division a-family smoking prevention and tobacco control act. Public Law 2009;111:31.

17. Department of Health and Human Services. National Survey on Drug Use and Health. Methodology Reports and Questionnaires. 2009. http://www.oas.samhsa.gov/nsduh/methods.cfm (accessed 18 Apr 2013)

18. Tynan MA, Morris D, Weston T. Continued implications of taxing roll-your-own tobacco as pipe tobacco in the USA. Tob Control2015;24:e125-7.

19. Cornelius ME, Driezen P, Fong GT, et al. Trends in the use of premium and discount cigarette brands: findings from the ITC US surveys (2002-2011). Tob Control 2014;23(Suppl 1):i48-53.

20. UBS Investment Research: Reynolds American. 6 January 2011.

21. Wells Fargo Statistics. Equity Research: Reynolds American, Inc., 12 February 2013.

22. Reynolds American Inc. Form $10 \mathrm{~K}$ Annual report. http:// reynoldsamerican.com/secfiling.cfm?filingID=950144-07-1653\&CIK= 1275283 Published 2/27/07 (accessed 7 Nov 2014).

23. Trinkets and Trash. Bright now- orange box for ultra-lights. http:// trinketsandtrash.org/detail.php?artifactid=5567\&page $=1$ (accessed Aug 2014).

24. Reynolds American shareholder report. 2009. http://files.shareholder com/downloads/RAl/3138416115×0x348889/a93bc9f6-7931-482a8b7d-2b16d03d8a6e/2010-04 RAls_2009 performance highlights underlying_strength_and_resilience.pdf. Published 4 February 2010 (accessed Nov 2014).

25. Reynolds American shareholder report. 2011. http://files.shareholder com/downloads/RAl/3185268357x0x541001/ 6c157143-28e3-4bb9-ae47-c9ea03df9358/2012-03 RAl delivers solid_earnings_growth_in_2011.pdf. Published 8 February 2012 (accessed Nov 2014)

26. Kelly KJ, Manning $\mathrm{K}$ The effects of natural cigarette claims on adolescents' brand-related beliefs, attitudes, and intentions. J Health Commun 2014;19:1064-75.

27. Czoli CD, Hammond D Cigarette packaging: Youth perceptions of "natural" cigarettes, filter references, and contraband tobacco. $J$ Adolesc Health 2014;54:33-9.

28. Reynolds American (RAl) Stock Dips After Announcing Acquisition of Lorillard (LO). The Street. 7/15/2014. http://www.thestreet.com/ story/12774129/1/reynolds-american-rai-stock-dips-after-announcingacquisition-of-lorillard-lo.html (accessed Nov 2014). 
29. Arrazola RA, Neff LJ, Kennedy SM, et al. Tobacco use among middle and high school students-United States, 2013. MMWR Morb Mortal Wkly Rep 2014;63:1021-6.

30. Centers for Disease Control and Prevention (CDC). Tobacco product use among middle and high school students-United States, 2011 and 2012. MMWR Morb Mortal Wkly Rep 2013;62:893.

31. Cummings KM, Hyland A, Lewit E, et al. Use of discount cigarettes by smokers in 20 communities in the United States, 1988-1993. Tob Control 1997;6(Suppl 2):S25.

32. Cruz TB. Monitoring the tobacco use epidemic IV. The vector: tobacco industry data sources and recommendations for research and evaluation. Prev Med 2009;48:S24-34.

33. O'Connor RJ, Cummings KM, Rees VW, et al. Surveillance methods for identifying, characterizing, and monitoring tobacco products: potential reduced exposure products as an example. Cancer Epidemiol Biomarkers Prev 2009;18: 3334-48.
34. Cummings KM, Hyland A, Peckacek T, et al. Comparison of recent trends in adolescent and adult cigarette smoking behavior and brand preferences. Tob Control 1997;6(Suppl 2):S31.

35. O'Connor RJ, et al. Relationship of cigarette-related perceptions to cigarette design features: findings from the 2009 ITC US Survey. Nicotine Tob Res 2013;15:1943-7.

36. Connolly GN, Alpert HR. Trends in the use of cigarettes and other tobacco products, 2000-2007. JAMA 2008;299:2629-30.

37. Agaku IT, King BA, Dube SR. Current cigarette smoking among adults-United States, 2005-2012. MMWR Morb Mortal Wkly Rep 2014;63:29-34.

38. Bunnell RE, Ralph S. Tobacco Use Among Middle and High School Students-United States, 2011-2014.

39. Maxwell J. The Maxwell Report: Year End and Fourth Quarter 2013 Sales and Volume Estimates for the U.S. Cigarette Industry. Richmond, VA: John C. Maxwell, Jr., 2014.

40. Difranza JR, Eddy JJ, Brown LF, et al. Tobacco acquisition and cigarette brand selection among youth. Tob Control 1994;3:334. 